\title{
Interleukin 1 Suppresses Expression of Cartilage-specific Types II and IX Collagens and Increases Types I and III Collagens in Human Chondrocytes
}

\author{
Mary B. Goldring, "* James Birkhead, ${ }^{\star \star}$ Linda J. Sandell, \\ *Departments of Medicine, and "Anatomy, Harvard Medical School; ${ }^{\S}$ Department of Biochemistry, Rush-Presbyterian St. Luke's \\ Medical Center, Chicago, Illinois 60612; and ${ }^{\ddagger}$ the Medical Services (Arthritis Unit), Massachusetts General Hospital, \\ Boston, Massachusetts 02114
}

\begin{abstract}
In inflammatory diseases such as rheumatoid arthritis, functions of chondrocytes including synthesis of matrix proteins and proteinases are altered through interactions with cells of the infiltrating pannus. One of the major secreted products of mononuclear inflammatory cells is IL-1. In this study we found that recombinant human IL-1 $\beta$ suppressed synthesis of cartilage-specific type II collagen by cultured human costal chondrocytes associated with decreased steady state levels of $\alpha 1$ (II) and $\alpha 1(I X)$ procollagen mRNAs. In contrast, IL-1 increased synthesis of types I and III collagens and levels of $\alpha 1(I), \alpha 2(I)$, and $\alpha 1$ (III) procollagen mRNAs, as we described previously using human articular chondrocytes and synovial fibroblasts. This stimulatory effect of IL-1 was observed only when IL-1stimulated $\mathrm{PGE}_{2}$ synthesis was blocked by the cyclooxygenase inhibitor indomethacin. The suppression of type II collagen mRNA levels by IL-1 alone was not due to IL-1-stimulated PGE $_{2}$, since addition of indomethacin did not reverse, but actually potentiated, this inhibition. Continuous exposure of freshly isolated chondrocytes from day 2 of culture to approximately half-maximal concentrations of IL-1 (2.5 pM) completely suppressed levels of type II collagen mRNA and increased levels of types I and III collagen mRNAs, thereby reversing the ratio of $\alpha 1$ (II)/ $\alpha 1$ (I) procollagen $m R N A s$ from $>6.0$ to $<1.0$ by day 7 . IL-1, therefore, can modify, at a pretranslational level, the relative amounts of the different types of collagen synthesized in cartilage and thereby could be responsible for the inappropriate repair of cartilage matrix in inflammatory conditions.
\end{abstract}

\section{Introduction}

In disorders such as rheumatoid arthritis interactions of inflammatory cells with the normal resident populations of cells

Presented in part at the 51st Annual Meeting of the American Rheumatism Association, June 1987, in Washington, DC, and was published in abstract form in 1987. (Arthritis Rheum. 30:S129.)

Dr. Sandell's present address is Department of Orthopedics, University of Washington, Seattle, WA 98195. Dr. Kimura's present address is Department of Orthopedic Surgery, Osaka University Medical School, 1-1-50 Fukushima-Ku, Osaka 553, Japan.

Address reprint requests to Dr. M. B. Goldring, Department of Medicine, Arthritis Unit, Massachusetts General Hospital, Boston, MA 02114.

Received for publication 29 February 1988 and in revised form 22 June 1988.

J. Clin. Invest.

(C) The American Society for Clinical Investigation, Inc. $0021-9738 / 88 / 12 / 2026 / 12 \$ 2.00$

Volume 82, December 1988, 2026-2037 present in cartilage, bone, and synovium results in destruction of joint tissues (1). It is generally accepted that erosion of cartilage collagen occurs in areas contiguous with the proliferating synovial pannus and to some extent at the cartilage surface exposed to synovial fluid $(2,3)$. Loss of cartilage proteoglycan, however, occurs early in the disease and is widespread throughout the cartilage and not limited to the synovialpannus junction (4). Degradation of collagen has also been observed in midzone pericellular regions of articular cartilage in humans with arthritis and in certain animal models of inflammation $(4,5)$. Chondrocytes can be induced to produce substances involved in breakdown of their own matrix by products of cells of the rheumatoid synovium (6-8) or isolated inflammatory cells $(7,9)$. Since chondrocytes normally function to produce new extracellular matrix and to repair the damaged collagen network (10), inflammatory mediators might also influence the synthesis of structural matrix components involved in these attempts at repair (11).

IL- 1 is an inflammatory mediator produced predominantly by monocytes that stimulates synthesis of $\mathrm{PGE}_{2}$, neutral metalloproteinases (such as collagenase), and serine proteinases (including plasminogen activator) by human chondrocytes and synovial fibroblasts (12-18). We and others have demonstrated that IL-1 also increases synthesis of types I and III collagens by dermal fibroblasts (19-22). In human chondrocytes and synovial fibroblasts, however, IL-1-induced increases in type I collagen synthesis and mRNA levels can be demonstrated only when ambient levels of $\mathrm{PGE}_{2}$ are suppressed by the cyclooxygenase inhibitor indomethacin (20). The purpose of the present studies was to determine whether the synthesis of the major cartilage-specific collagen, type II collagen, is modulated by IL-1.

We previously observed that in chondrocytes the T lymphocyte product, IFN- $\gamma$, decreases the synthesis of types I, II, and III collagens and the levels of their associated procollagen mRNAs (23). These effects of IFN- $\gamma$ are not modulated by $\mathrm{PGE}_{2}$. In the present study, we found in early primary cultures of human costal chondrocytes that IL-1 suppresses type II collagen synthesis as well as the levels of $\alpha 1$ (II) procollagen mRNA. In contrast to the effects of IL-1 on the synthesis of types I and III collagens, the addition of indomethacin does not overcome the suppression of type II collagen synthesis but even potentiates it. Furthermore, our results indicate that this suppression of cartilage-specific type II collagen synthesis by IL-1 is exerted at a pretranslational level.

\section{Methods}

Cell cultures. Costal cartilage was obtained from ribs removed during pectus excavatum repair and articular cartilage from the knee during joint replacement after injury due to trauma. Chondrocytes were iso- 
lated by dispersion with proteinases as described previously (23), except that serum was not present in the final incubation of costal cartilage with collagenase (Worthington Biochemical Corp., Freehold, NJ). A single cell suspension was obtained after incubation for $36-48 \mathrm{~h}$ with $\geq 95 \%$ of the cells viable as estimated by trypan blue exclusion. The chondrocytes were plated, unless otherwise indicated, at a density of $\sim 2.0 \times 10^{4} \mathrm{cells} / \mathrm{cm}^{2}$ in 22-mm diam wells (Tissue Culture Cluster 12; Costar, Cambridge, MA) or in 100-mm diam dishes (Falcon Labware, Oxnard, CA) and cultured in Dulbecco's modified Eagle's medium (DME) with $10 \%$ FCS with changes of medium every 3-4 d. The collagens synthesized by human chondrocytes cultured under these conditions were characterized previously (23). Cells isolated from costal cartilage from three different individuals were used for the experiments described in this study. Similar results were obtained using costal chondrocytes isolated from five additional specimens.

Collagen synthesis. 1 or 2 wk primary cultures of chondrocytes in triplicate 22-mm wells were preincubated without or with human recombinant IL-1 $\beta$ (24) (kindly provided by Drs. Paul Wingfield and Alan Shaw, Biogen, Geneva, Switzerland) for 24 or $48 \mathrm{~h}$ in DME with $10 \%$ FCS $(0.75 \mathrm{ml}$ per well $)$. The cells were then labeled with L- $\left[5-{ }^{3} \mathrm{H}\right]$ proline $(22 \mathrm{Ci} / \mathrm{mmol}$; Amersham Corp., Arlington Heights, IL) in the absence of serum for a further $24 \mathrm{~h}$ at $37^{\circ} \mathrm{C}$. Labeled medium proteins and pepsin-resistant collagens were analyzed by SDS-PAGE (5\% acrylamide, $12-\mathrm{cm}$ path length) and fluorography and DNA content in cell layers was measured as described previously $(20,23)$. In some cases the pepsin-resistant collagen bands were excised from gels, incubated for $2 \mathrm{~h}$ at $25^{\circ} \mathrm{C}$ with $10 \mathrm{mg} / \mathrm{ml}$ of $\mathrm{CNBr}$ in $70 \%$ formic acid (25) and the CNBr peptides analyzed by SDS-PAGE.

Extractions of RNA. Cytoplasmic RNA $\left(\sim 1-4 \times 10^{6}\right.$ cells $/ 100 \mathrm{~mm}$ dish for each extraction) was extracted from cells by the method of White and Bancroft (26). Total RNA $\left(10-40 \times 10^{6}\right.$ cells per incubation condition) was extracted by a method adapted from Cox (27) and Strohman et al. (28). The average yield of extracted total RNA was 85 $\mu \mathrm{g} / 10^{7}$ cells as measured by absorption at $260 \mathrm{~nm}$ and the average ratio of absorption at 260:280 was $\sim 2.08$.

Dot blot and Northern blot hybridizations. Dot blots of cytoplasmic or total RNA were performed as described $(20,23)$. For Northern blot analysis total cellular RNAs were denatured by treatment with formaldehyde-formamide, electrophoresed on $0.8 \%$ agarose gels containing $0.22 \mathrm{M}$ formaldehyde, and transferred to nitrocellulose paper in $20 \times \mathrm{SSC}$ buffer $(1 \times \mathrm{SSC}=0.15 \mathrm{M} \mathrm{NaCl}, 0.015 \mathrm{M}$ sodium citrate, $\mathrm{pH}$ 7.5). Staining of the $28 \mathrm{~S}$ and $18 \mathrm{~S}$ bands with $\mathrm{EtBr}$ was used to monitor quality of the RNA preparation and uniform loading of RNA in all of the lanes. Nick translation, prehybridization, and hybridization were performed as described (23). The type I procollagen $\mathrm{cDNA}$ probes used were Hf677, a 1,500-bp cDNA encoding part of the $\alpha 1$ (I) procollagen subunit (29), and Hf1 131, a 1,500-bp cDNA encoding part of the $\alpha 2$ (I) procollagen subunit (30) (kindly provided by Dr. F. Ramirez, SUNY Health Science Center, Brooklyn, NY, and Dr. D. J. Prockop, Jefferson Medical College, Philadelphia, PA). The DNA probe for human $\alpha 1$ (II) procollagen, a 3.8-kb genomic fragment ( $\mathrm{HgCol}[\mathrm{II}])$, which encodes from amino acid 892 to the end of the C-propeptide $(\sim 1,150$ nucleotides of exon material), was purified from a lambda Charon $4 \mathrm{~A}$ bacteriophage containing the $3^{\prime}$ half of the human type II collagen gene. The clone $\mathrm{HgCol}(\mathrm{II})$ was isolated using a chick type II collagen gene fragment and identified by DNA sequence analysis (31, 32; Sandell, L. J., manuscript in preparation). A cDNA for $\alpha 1$ (III) procollagen (pHC-III-1), was kindly provided by Drs. R. J. Crystal and M. Brantly, National Institutes of Health (33). Dot blots could be compared quantitatively, since these probes are of similar size and of adequate length to avoid cross-hybridization due to highly conserved sequences. The probe for type IX collagen (KTh123), a 600-bp cDNA encoding part of the $\alpha$ (IX) subunit was selected from a cDNA library prepared from human costal chondrocyte mRNA using a 627 bp Eco RI fragment from the $5^{\prime}$ region of the rat $\alpha$ l(IX) cDNA pKt1643 (33a). The probe for human $\beta$-actin was a 700-bp Eco RI-Bam HI fragment of pHF $\beta$ A-3'UT (34) subcloned in pGEM3 kindly provided by Dr. David Kwiatkowski, Massachusetts General Hospital. Specific activities of the labeled probes were similar within each experiment and varied between 0.5 and $1.75 \times 10^{8} \mathrm{cpm} / \mu \mathrm{g}$ of DNA. The specific activity of the labeled $\alpha 1$ (II) procollagen DNA probe was usually approximately one-half that of the $\alpha 1$ (I) procollagen probe. Kodak X-Omat XAR-5 film was exposed to the blots for various lengths of time at $-80^{\circ} \mathrm{C}$ with Dupont Cronex Lightening-Plus intensifying screens (35) and scanned with a soft laser scanning densitometer (model SL-504-XO; Biomed Instruments, Inc., Fullerton, CA). The scans were analyzed with an Apple Ile computer using a Zeineh Videophoresis II electrophoresis reporting integrator program. Several exposures were scanned to insure that the band intensities were within the linear response range of the film and the values adjusted for the specific activities of the probes.

Prostaglandin assay. Chondrocyte-conditioned medium was removed from cells and stored at $-20^{\circ} \mathrm{C}$ until assay. Concentrations of $\mathrm{PGE}_{2}$ in the culture medium were determined using the $\mathrm{PGE}_{2}{ }^{125} \mathrm{I}-\mathrm{RIA}$ kit (DuPont, New England Nuclear, Boston, MA). Standard $\mathrm{PGE}_{2}$ was obtained from Pharmacia Fine Chemicals (Piscataway, NJ).

\section{Results}

In our previous studies of human articular chondrocytes and synovial fibroblasts, we showed that recombinant human IL- $1 \beta$ or murine IL- $1 \alpha$ increased synthesis of types I and III collagens and the levels of associated procollagen mRNAs. This increase was observed only when the synthesis of $\mathrm{PGE}_{2}$ was blocked by indomethacin (20). In this study, human costal, as well as articular, chondrocytes were used to examine the effects of recombinant human IL- $1 \beta$ on type II collagen synthesis and the levels of type II procollagen mRNAs. The $\alpha 1$ (I), $\alpha 2(\mathrm{I}), \alpha 1$ (II), and $\alpha 1$ (III) procollagen mRNAs extracted from costal chondrocytes at day 13 of primary culture were analyzed by Northern hybridization. Control chondrocytes or chondrocytes preincubated for $48 \mathrm{~h}$ with IL-1, indomethacin or $\mathrm{PGE}_{2}$ alone or in combination were examined (Fig. $1 \mathrm{~A}$ ). The predominant species of procollagen mRNA in these cells was $\alpha 1$ (II) (5.5 kb). However, $\alpha 1$ (I) procollagen mRNA (5.9 and $7.2 \mathrm{~kb}$ ) was also present in lesser abundance. The levels of both $\alpha$ (II) and $\alpha 1$ (I) procollagen mRNAs were markedly decreased in cells incubated with IL-1 alone. Although the IL-1induced decrease in $\alpha 1$ (I) procollagen mRNA levels was reversed by coincubation with indomethacin, addition of this cyclooxygenase inhibitor did not overcome the suppression of the levels of $\alpha 1$ (II) procollagen mRNA, but potentiated this suppression. The suppression by IL-1 of the levels of $\alpha 1$ (I) mRNA could be ascribed to the IL-1-induced increases in endogenous $\mathrm{PGE}_{2}$, since coincubation of cells with IL-1 and indomethacin completely reversed this inhibition and unmasked a stimulatory effect on the major $(5.9 \mathrm{~kb})$ polymorphic $\alpha 1$ (I) procollagen mRNA species. Furthermore, addition of $100 \mathrm{ng} / \mathrm{ml}$ of $\mathrm{PGE}_{2}$ to cultures incubated with IL-1 in the presence of indomethacin suppressed the levels of $\alpha 1$ (I) procollagen mRNA to those found with IL-1 alone. In contrast, $\mathrm{PGE}_{2}$ overcame the further suppression by indomethacin of IL-1-induced decrease in levels of $\alpha$ (II) procollagen mRNA but did not restore these levels to control values. In overexposed autoradiographs (Fig. $1 \mathrm{~B}$ ), IL-1 alone suppressed the levels of $\alpha 2$ (I) $(5.5,5.7$, and $6.2 \mathrm{~kb})$ and $\alpha 1$ (III) (4.5 and $6.2 \mathrm{~kb}$ ) procollagen $\mathrm{mRNAs}$ and indomethacin partially reversed the suppression of $\alpha 2$ (I) procollagen mRNA while unmasking a stimulatory effect particularly on the $4.5-\mathrm{kb}$ transcript of $\alpha 1$ (III) mRNA. We have previously reported that $\alpha 2$ (I) procollagen mRNA levels are not as tightly regulated as levels of 


\section{Costal Chondrocyte mRNA}

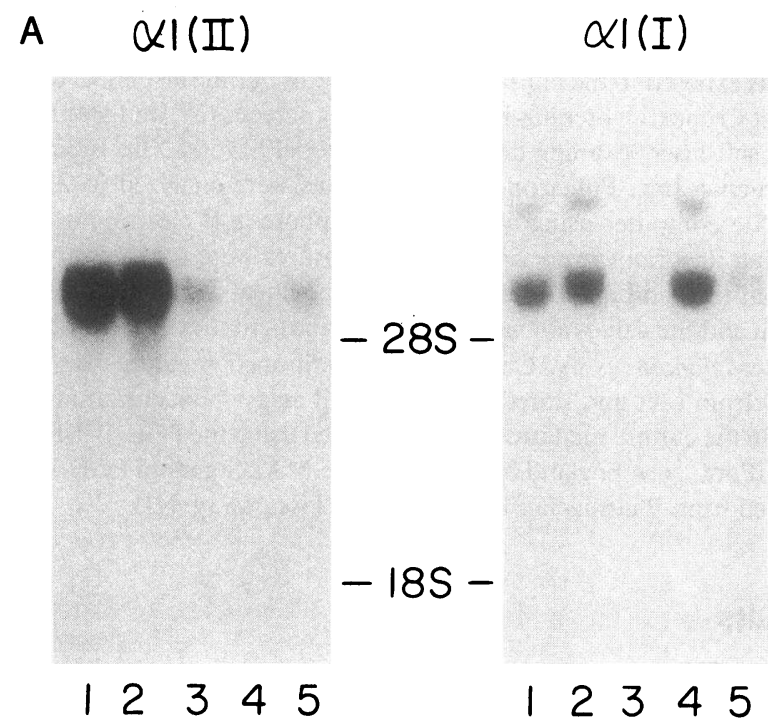

B

$\alpha \mid(I I)$

Costal Chondrocyte mRNA

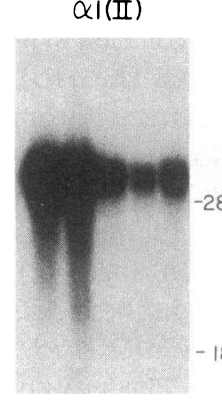

12345

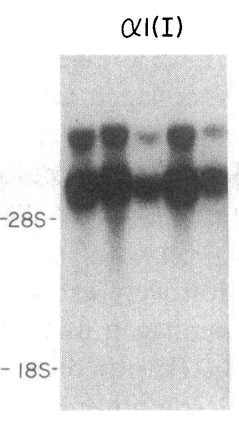

12345 $\alpha 2(I)$

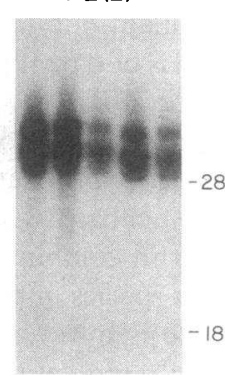

12345 $\alpha \mid(I I)$

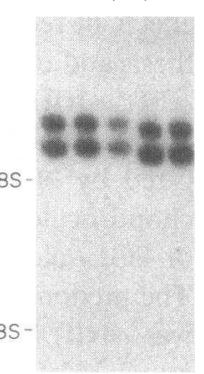

12345

$\alpha 1$ (I) procollagen mRNA $(20,23,36)$. Similar effects of IL-1 and indomethacin were observed using articular chondrocytes at day 14 of primary culture, although $\alpha 1$ (I) was more abundant than $\alpha 1$ (II) procollagen mRNA (Fig. $1 B$ ) in these cultures. These changes in procollagen $m R N A$ levels could not be accounted for by any changes in $\beta$-actin mRNA levels (data not shown).

IL-1 also suppressed the levels of mRNA for $\alpha 1$ (IX) procollagen, another cartilage-specific collagen. Northern blot analyses of $\alpha$ l(IX) procollagen mRNA from two different costal chondrocyte cultures, including that shown in Fig. 1, are shown in Fig. 2. While the signal for type IX procollagen mRNA was relatively strong in control or indomethacintreated cultures ( $\sim 5 \%$ of the signal for $\alpha 1$ (II) procollagen mRNA), IL-1 completely suppressed the levels of $\alpha 1$ (IX) procollagen mRNA. Further modulation of the IL-1-suppressed signal by indomethacin or $\mathrm{PGE}_{2}$ was not discernible.

Changes in cellular morphology were also noted in cultures of chondrocytes incubated for $48 \mathrm{~h}$ with IL-1, indomethacin, and $\mathrm{PGE}_{2}$. Increased mitotic figures were observed in the presence of indomethacin (Fig. 3, panel 2). Cells with stellate shape were found in cultures incubated with IL-1 alone, (Fig. 3, panel 3) or with supplements of $\mathrm{PGE}_{2}$ (Fig. 3, panel 5). An

\section{Articular Chondrocyte mRNA}

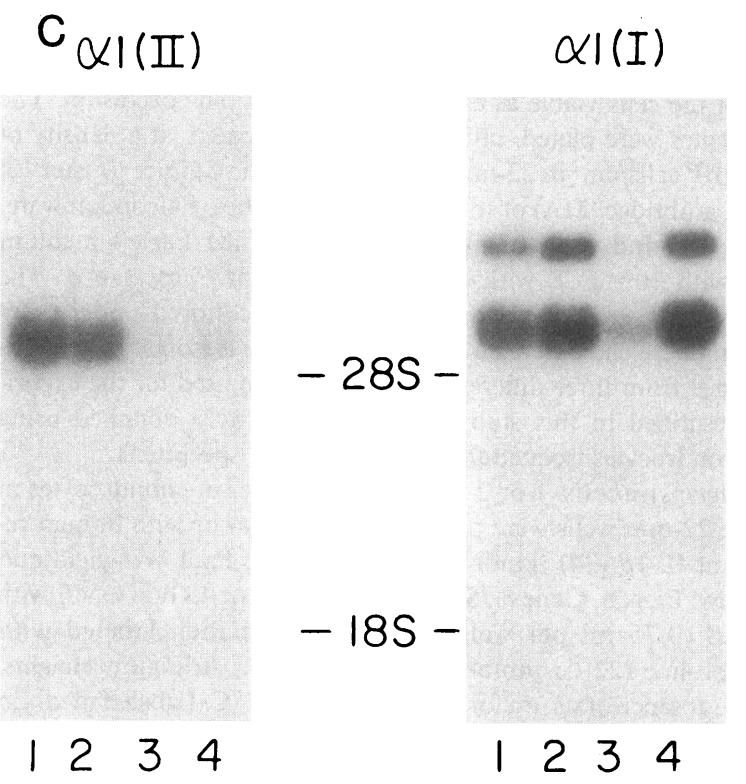

Figure 1. Northern hybridization analysis of $\alpha 1(\mathrm{II}), \alpha 1(\mathrm{I}), \alpha 2(\mathrm{I})$ and $\alpha 1$ (III) procollagen mRNAs in human costal and articular chondrocytes after incubation with IL-1, indomethacin, and $\mathrm{PGE}_{2}$. $(A$ and $B)$ Costal chondrocytes (male, $71 / 2$ ) on day 11 of primary culture were incubated for $48 \mathrm{~h}$ or $(C)$ articular chondrocytes (female, 22) on day 13 of primary culture were incubated for $24 \mathrm{~h} \mathrm{(1)}$ alone, or with (2) indomethacin $(1 \mu \mathrm{M}),(3) \mathrm{IL}-1$ (5.0 pM), (4) IL-1 and indomethacin or (5) IL-1, indomethacin, and $\mathrm{PGE}_{2}(100 \mathrm{ng} / \mathrm{ml})$. Total cellular RNA was then extracted, denatured by treatment with formaldehyde-formamide, electrophoresed on $0.8 \%$ agarose gels (5 $\mu \mathrm{g}$ RNA/ well) and transferred to nitrocellulose. A separate blot was prepared for hybridization with each nick-translated ${ }^{32} \mathrm{P}$-labeled DNA probe. Films were exposed to blots for $(A) 5.5 \mathrm{~h}$, and $(B) 18.5 \mathrm{~h}$, and $(C) 42$ $\mathrm{h}$ for $\alpha 1$ (II) and $22 \mathrm{~h}$ for $\alpha 1$ (I) procollagen mRNAs. Densitometric scans of dot blots of the total RNAs used in $A$ and $B$ demonstrated $\sim 1.5$-fold increases in $\alpha 1$ (I) and $\alpha 1$ (III) procollagen mRNA levels in lane 4 compared with lane 2 .

\section{$\alpha 1(\mathrm{IX})$ Procollagen mRNA}
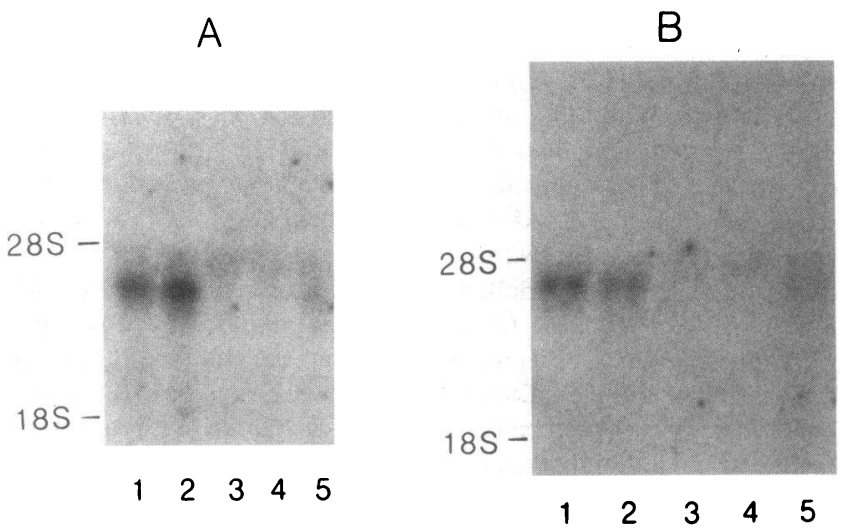

Figure 2. Effects of IL-1 on $\alpha 1$ (IX) procollagen mRNA in human costal chondrocytes. Chondrocytes isolated from two separate specimens ( $A$, female, 4 , day 13 of culture; $B$, male, $71 / 2$, day 11 of culture, see Fig. 1) were preincubated for $48 \mathrm{~h}(1)$ alone or with (2) indomethacin (1 $\mu \mathrm{M})$, (3) IL-1 (5.0 pM), (4) IL-1 and indomethacin, or (5) IL-1, indomethacin and $\mathrm{PGE}_{2}(100 \mathrm{ng} / \mathrm{ml})$. Northern blots of total RNAs were hybridized to ${ }^{32} \mathrm{P}$-labeled human $\alpha 1$ (IX) cDNA (KTh123). Films were exposed to the blots for $7 \mathrm{~d}$. 


\section{Human Costal Chondrocytes}
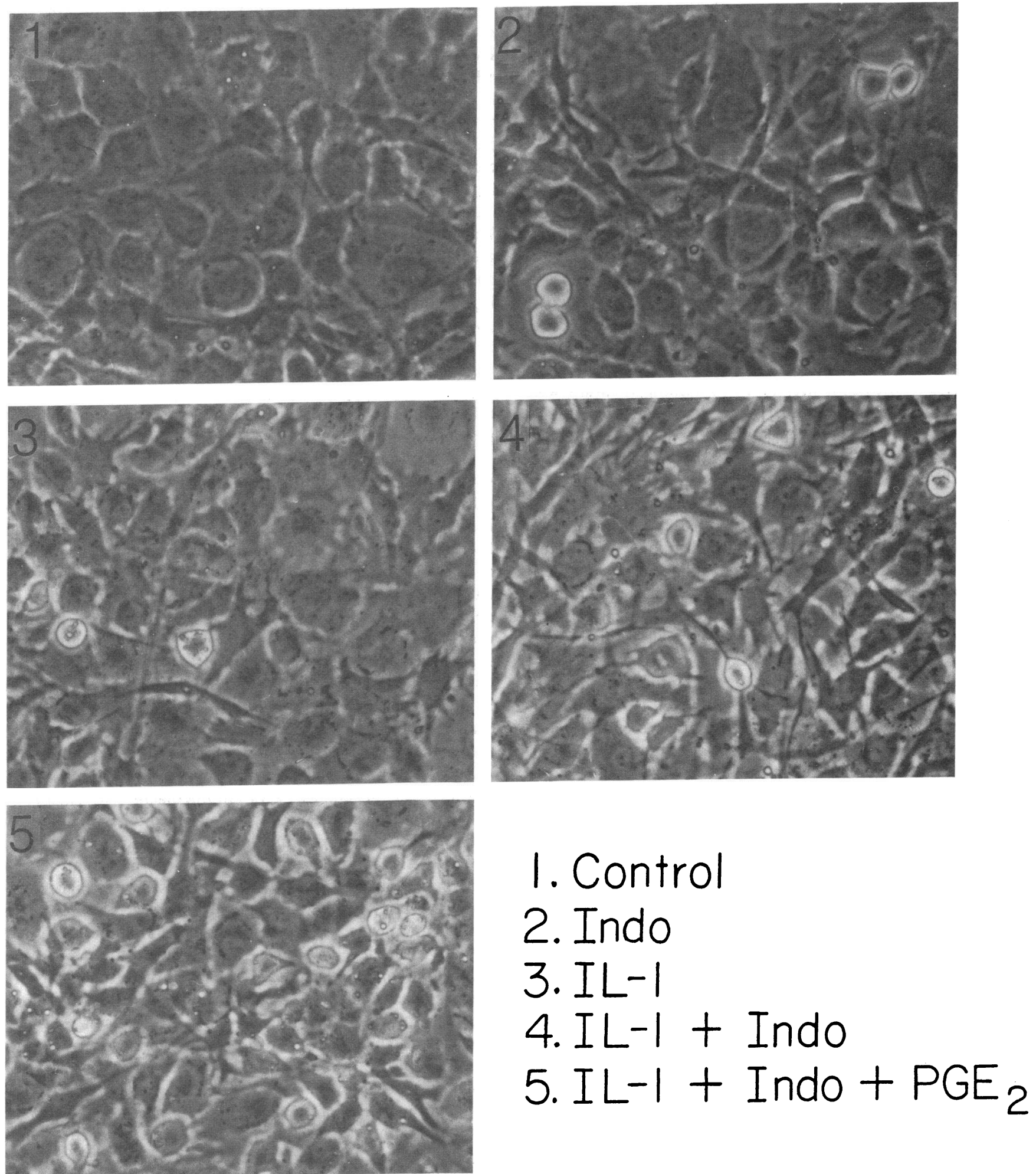

Figure 3. Effects of IL-1, indomethacin, and $\mathrm{PGE}_{2}$ on morphology of human costal chondrocytes. The cells used for the Northern blots shown in Fig. 1 were photographed before extraction of RNA. Cells were preincubated for $48 \mathrm{~h}(1)$ alone or with (2) indomethacin, (3) IL-1, (4) IL-1 and indomethacin or (5) IL-1, indomethacin and $\mathrm{PGE}_{2}$. 
increase in the numbers of cells with fibroblast morphology was observed in cultures incubated with IL-1, particularly in the presence of indomethacin (Fig. 3, panel 4), a condition in which the most marked enhancement of synthesis of types I and III collagens and levels of procollagen mRNA was observed.

We had previously determined that $\sim 2.5 \mathrm{pM}$ is the halfmaximal concentration of IL- $\beta$ required for stimulation of $\mathrm{PGE}_{2}$ production and type I and III collagen synthesis by articular chondrocytes and synovial fibroblasts (20). Concentrations between 0.1 up to $5 \mathrm{pM}$ produced dose-dependent inhibition of type II collagen mRNA levels (50\% inhibitory dose $\sim 2.5 \mathrm{pM}$ ) (manuscript in preparation). A concentration of 5 pM IL-1 $\beta$ produced maximal stimulation of synthesis of types I and III collagens with no further stimulation or inhibition at supermaximal concentrations up to $2.5 \mathrm{nM}$ (data not shown).

To explore further the effects of IL-1 on the phenotype of costal chondrocytes, IL-1 at a concentration of $2.5 \mathrm{pM}$ was added to cells on day 2 of primary culture. Thereafter, at each change of medium (every 3-4 d) IL-1 (without or with indomethacin) was added. On days $7,13,16$, and $20,24 \mathrm{~h}$ after the last change of medium, the serum-containing medium was collected for $\mathrm{PGE}_{2}$ assay and $\left[{ }^{3} \mathrm{H}\right]$ proline was added in the absence of serum for a further $24 \mathrm{~h}$ or the cells were extracted to obtain cytoplasmic RNA for dot blot hybridization. Analysis by SDS-PAGE of these $\left[{ }^{3} \mathrm{H}\right]$ proline-labeled total medium proteins and pepsin-resistant collagens are shown in Fig. $4 \mathrm{~A}$ and $B$, respectively. On days 7,13 , and 16 , the incorporation of $\left[{ }^{3} \mathrm{H}\right]$ proline into fibronectin (FN) and the major procollagen bands migrating between FN and $\alpha 1$ (I) collagen was markedly increased by IL-1, particularly in the presence of indomethacin. When the procollagens were digested with pepsin under nondenaturing conditions, it was then possible to distinguish the $\alpha 1$ (I), $\alpha 2(\mathrm{I})$, and $\alpha 1$ (III) collagen chains synthesized (Fig. 4 $B$ ). The synthesis of $\alpha 1$ (III) collagen, identified by delayed reduction was stimulated at all time points by IL-1 alone and this stimulation was further enhanced in the presence of indomethacin. In overexposed SDS-PAGE gels (data not shown), $\alpha 1$ (III) or $\alpha 2$ (I) collagen chains were not discerned at day 7 unless the cells had been exposed to IL-1. In addition, increased amounts of $\alpha 2$ (I) collagen were observed at days 7, 13, and 16 after continuous incubation with IL-1 in the presence of indomethacin but not with IL-1 alone. This stimulation of the synthesis of $\alpha 2(\mathrm{I})$ collagen chains was no longer apparent by day 20 and the stimulatory effect on the synthesis of type III collagen had diminished. Labeling in the region of the $\alpha 1$ collagen band was also increased by IL-1 in the presence of indomethacin compared with IL-1 alone at days 7, 13, and 16 but not at day 20. The $\alpha 1$ collagen band in medium from cells incubated with IL-1 migrated more slowly than that from control cells at all time points and coincided with the migration of the $\alpha 1$ (I) collagen band from the rat tail tendon collagen standard. The labeled $\alpha 1$ collagen bands of higher mobility present in medium from control and indomethacin-treated cells and most easily distinguished at day 7 probably represent predominantly $\alpha 1$ (II) collagen chains. $\mathrm{CNBr}$ peptide analysis of the $\alpha 1$ band from lane 1 (day 7) demonstrated predominantly $\alpha$ (II) $\mathrm{CNBr}$ peptides, while $\mathrm{CNBr}$ peptides specific for types I and III collagens were present in lane 4 (data not shown). These results suggest that under these conditions IL-1 induced the synthesis of type I and III collagens, whereas it suppressed the synthesis of cartilage-specific type II collagen in early primary cultures of chondrocytes.

To explore this possibility further, cytoplasmic RNAs were extracted from parallel cultures on days $7,13,16$, and 20 and levels of $\alpha 1$ (I), $\alpha 2$ (I), $\alpha 1$ (II), and $\alpha 1$ (III) procollagen mRNAs analyzed by dot blot hybridization (Fig. 5 and Table I). Through day 20, type II was the predominant procollagen mRNA in control cells or cells incubated with indomethacin. In chondrocytes incubated under control conditions, the relative abundance of types I and III procollagen mRNAs increased with time in culture, whereas the levels of type II procollagen mRNA remained relatively constant. As shown in Fig. 5 and Table I, incubation with IL-1 increased the levels of $\alpha 1$ (I) and $\alpha 1$ (III) procollagen mRNAs at days 7, 13, and 16. The suppression by IL-1 alone of the levels of $\alpha 1$ (I) procollagen mRNA observed in the short-term incubations described above, which we ascribed to IL-1-induced increases in ambient $\mathrm{PGE}_{2}$ concentrations, was not observed during continuous exposure likely due to downregulation of cellular responsiveness to $\mathrm{PGE}_{2}$ as discussed below (see Table III). On the other hand, incubation with IL-1 alone or in the presence of indomethacin, dramatically suppressed the levels of $\alpha 1$ (II) procollagen mRNA at all time points and reversed the ratio of $\alpha 1$ (II)/ $\alpha 1$ (I) procollagen mRNAs from $>6.0$ to $<1.0$ (Table I).

In previous studies $(20,23)$ and in the experiments described above the chondrocytes were plated at $\sim 1.4-2.5 \times 10^{4}$ cells per $\mathrm{cm}^{2}\left(1.5-2.0 \times 10^{6}\right.$ cells per 100-mm dish). To examine the effects of cell density on the short-term responses to IL-1, costal chondrocytes were plated on day 0 at $0.5,1.0,1.5$, or $2.0 \times 10^{6}$ cells per $100-\mathrm{mm}$ dish and cultured until day 12 . At this time the cells had begun to synthesize types I and III collagens, but type II procollagen mRNA remained the predominant species (23). The morphology of the cells after plating varied as a function of the plating density (data not shown). At the highest plating density, the chondrocytes were confluent at day 7 . They appeared smaller and more polygonal than cells plated at lower densities. At the lower densities, cells were larger and took longer to reach confluence and an increase in cells with a fibroblast-like morphology was noted. On day 12 the medium was changed and indomethacin $(1 \mu \mathrm{M})$, IL-1 ( 5 pM), or IL-1 plus indomethacin was added for $24 \mathrm{~h}$ and cytoplasmic RNAs prepared for dot hybridizations. As shown in Table II, the ratios of the levels of $\alpha 1$ (II)/ $\alpha 1$ (I) and $\alpha 1$ (II)/ $\alpha 1$ (III) procollagen mRNA levels increased with higher cellplating density. Cells plated at all densities responded in a similar manner to IL-1 alone or IL-1 plus indomethacin with respect to the levels of types I and III procollagen mRNAs. IL-1 alone markedly decreased the levels of mRNAs for $\alpha 1$ (I) and $\alpha 2$ (I) procollagens, particularly at the lower plating densities. IL-1 plus indomethacin increased the levels of $\alpha 1$ (I) procollagen mRNA above those of cells incubated with indomethacin alone. In contrast, IL-1 decreased the levels of type II collagen mRNA by $70-90 \%$. This effect was not reversed by incubation in the presence of indomethacin. Furthermore, preincubation with IL-1 in the absence or presence of indomethacin reversed the ratio of $\alpha 1$ (II)/ $\alpha 1$ (I) procollagen mRNAs from $>3.0$ to $<1.0$ at all cell-plating densities. The levels of $\alpha 2$ (I) procollagen mRNA changed in the same direction but not to the same extent as those of $\alpha 1$ (I) procollagen mRNA. This observation supports the conclusions reached previously that the major determinant of the control of type I 

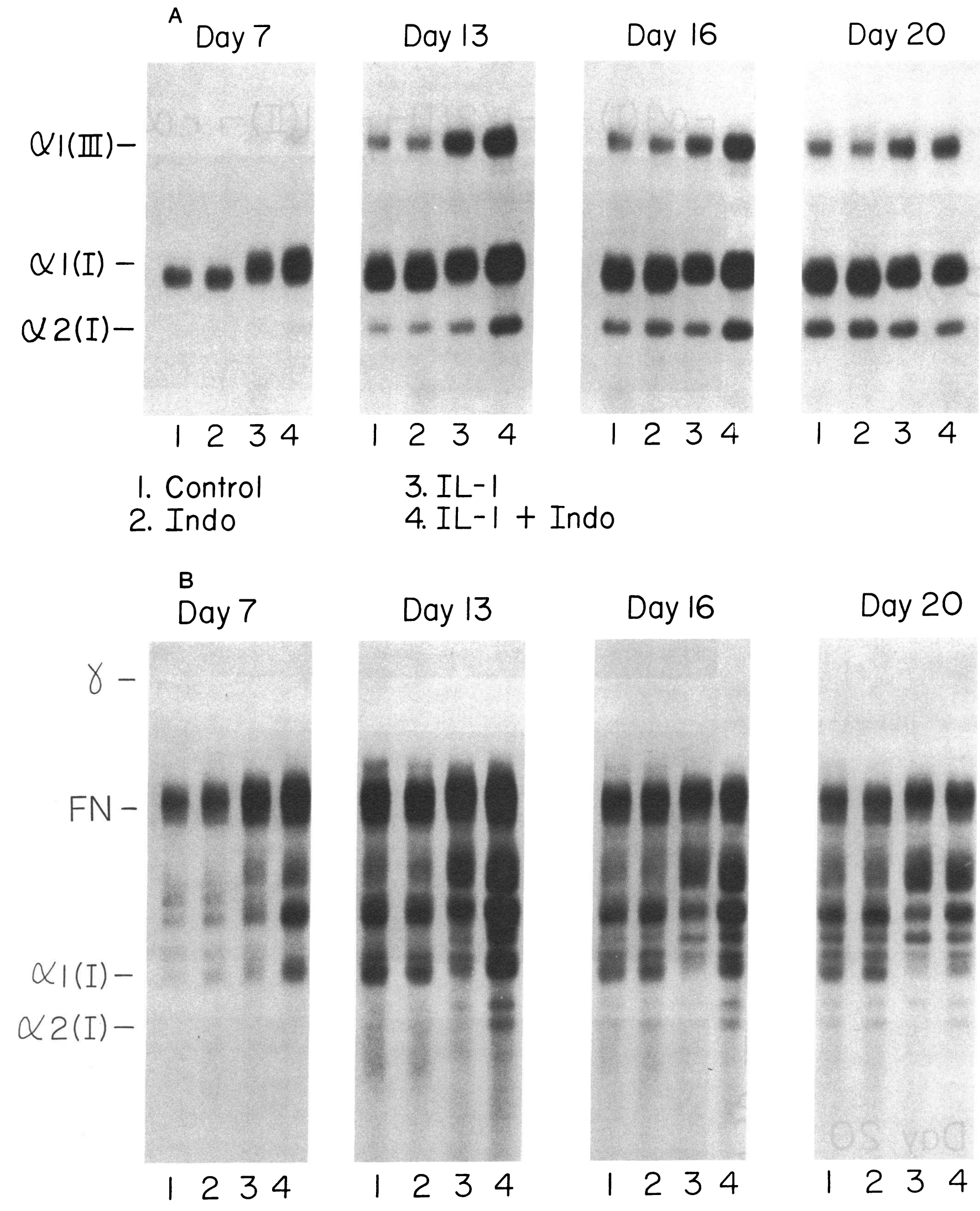

\section{IL-I \\ 4. IL-I + Indo}

Day 16

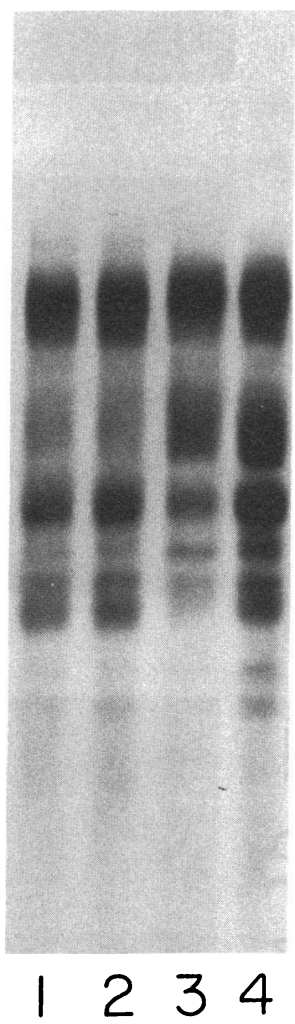

Day 20

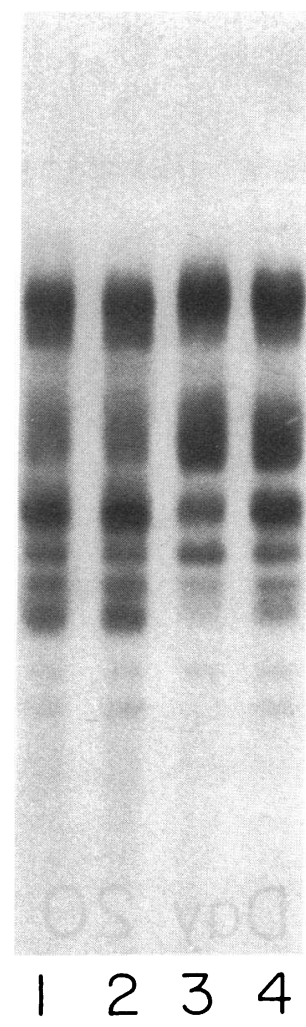

Figure 4. Fluorographs of $\left[{ }^{3} \mathrm{H}\right]$ proline-labeled proteins synthesized by human costal chondrocytes after long-term incubation with IL-1 and indomethacin. On day 2 of primary culture of chondrocytes (female, $51 / 2)$ and at each medium change, culture medium was removed and fresh DME with $10 \%$ FCS containing (1) no addition, (2) indomethacin (1 $\mu \mathrm{M})$, (3) IL-1 (2.5 pM), or (4) IL-1 and indomethacin was added. On days $7,13,16$, and $20(24 \mathrm{~h}$ after the previous medium change), the serum-containing preincubation medium was col- lected for subsequent $\mathrm{PGE}_{2}$ assay (see Table III) and the cells were incubated with $\left[{ }^{3} \mathrm{H}\right]$ proline in serum-free medium for a further $24 \mathrm{~h}$. SDS-PAGE ( $5 \%$ acrylamide) was then performed on $(A)$ total medium proteins ( $25 \mu$ l of original media) without (not shown) and with reduction with $0.1 \% 2$-ME or $(B)$ pepsin-resistant collagens ( 50 $\mu \mathrm{l}$ of original medium) without (not shown) and with delayed reduction with $0.5 \% 2$-ME. Films were exposed to gels for $(A) 4 \mathrm{~d}$ and $(B)$ 2 d. 


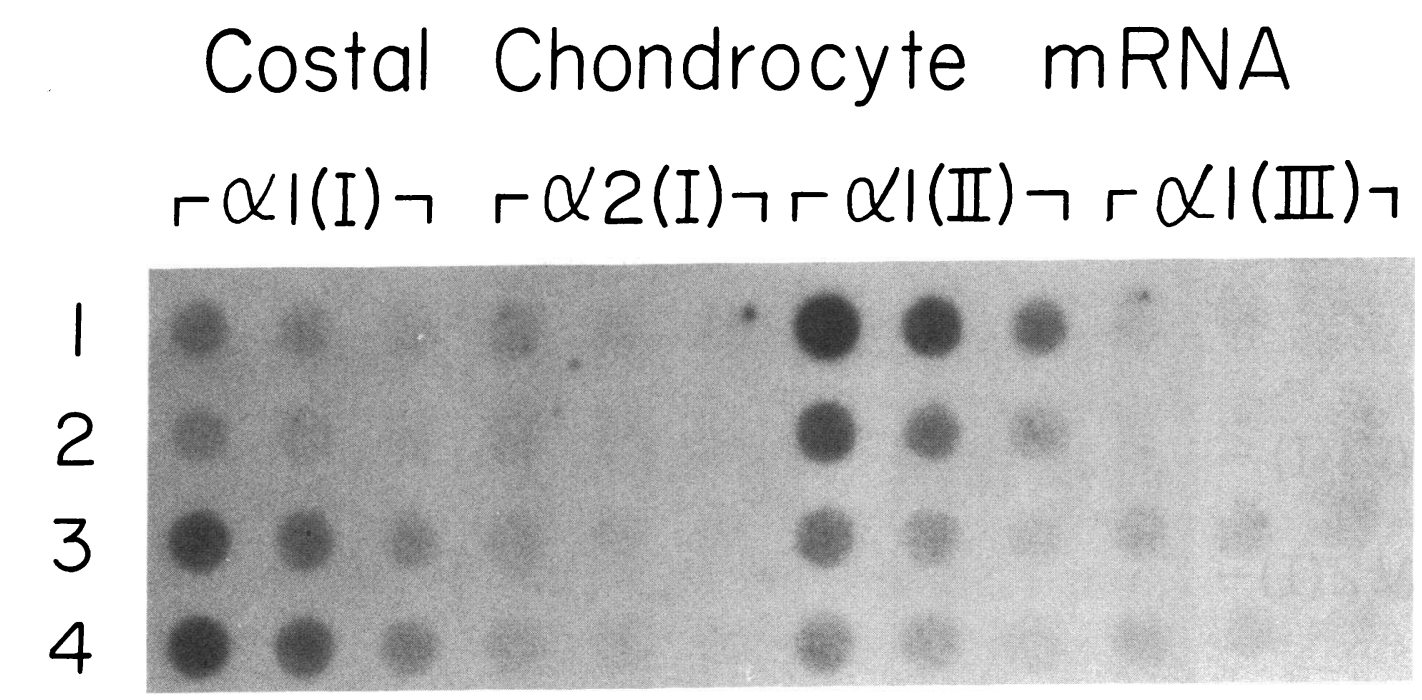

Day 7

Day 13

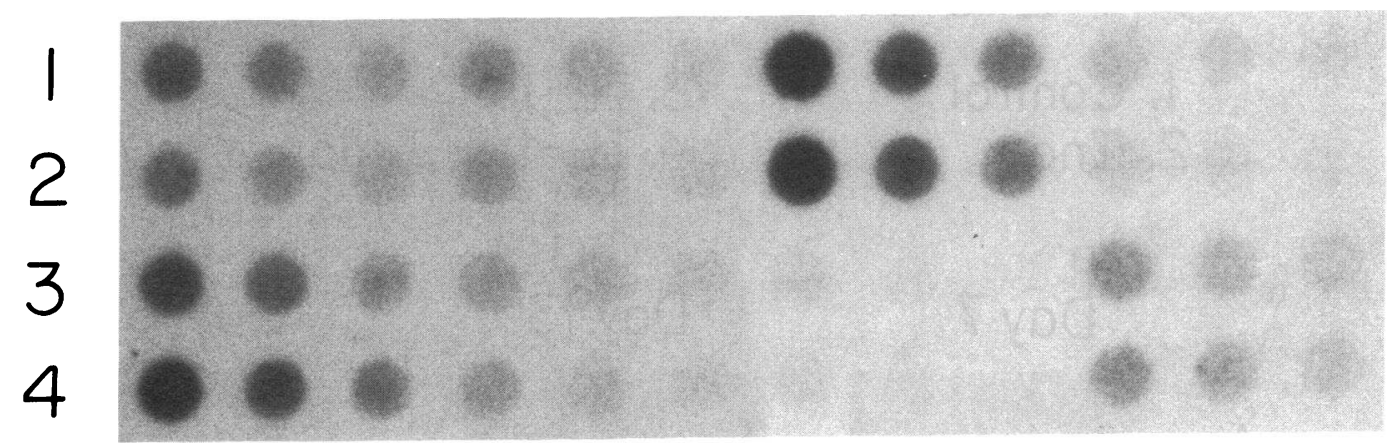

Day 16

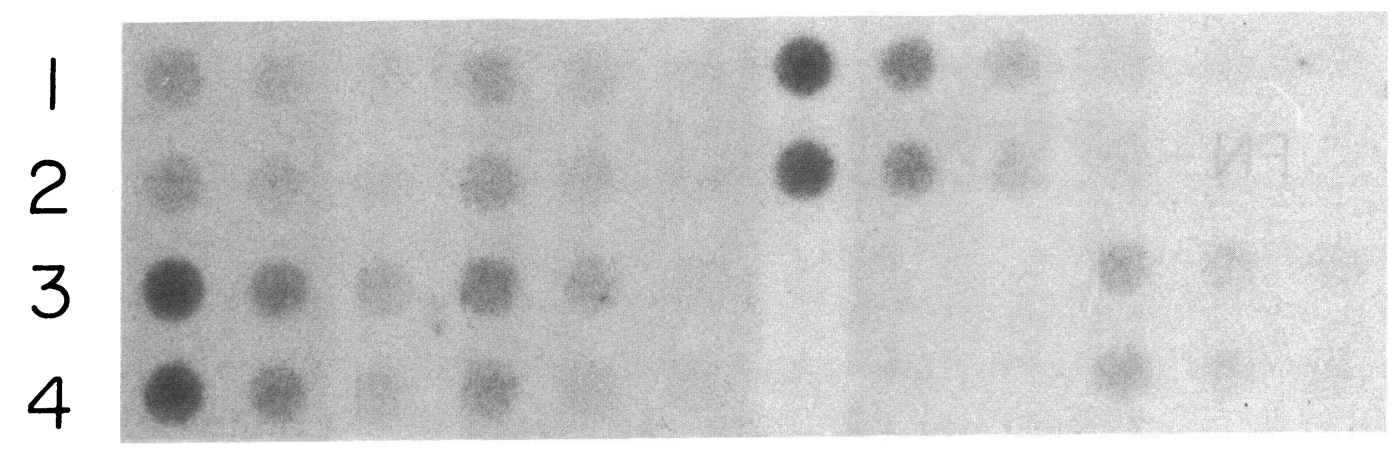

Day $20 \quad 2$

4
1. Control
3. IL-I
2. Indo
4. IL-I + Indo 
Table I. Procollagen mRNA Levels in Human Costal Chondrocytes after Continuous Treatment with IL-1 and Indomethacin

\begin{tabular}{|c|c|c|c|c|c|c|c|}
\hline \multirow{3}{*}{$\begin{array}{l}\text { Day of } \\
\text { culture }\end{array}$} & \multirow[b]{3}{*}{ Incubation conditions* } & \multicolumn{6}{|c|}{ Procollagen $m R_{N A}^{\ddagger}$} \\
\hline & & \multicolumn{4}{|c|}{ Treated/control ratios } & \multicolumn{2}{|c|}{ Ratios } \\
\hline & & $\alpha 1(\mathrm{I})$ & $\alpha 2(\mathrm{I})$ & $\alpha 1$ (II) & $\alpha 1$ (III) & $\alpha 1(\mathrm{II}) / \alpha \mathrm{l}(\mathrm{I})$ & $\alpha 1(\mathrm{I}) / \alpha 2(\mathrm{I})$ \\
\hline \multirow[t]{4}{*}{7} & Control & 1.0 & 1.0 & 1.0 & 1.0 & 12.05 & 3.59 \\
\hline & Indomethacin & 0.69 & 0.68 & 0.44 & 0.88 & 7.7 & 3.61 \\
\hline & IL-1 & 2.89 & 0.71 & 0.24 & 2.37 & 0.99 & 14.6 \\
\hline & IL-1 + Indomethacin & 3.55 & 0.37 & 0.18 & 1.72 & 0.61 & 34.6 \\
\hline \multirow[t]{4}{*}{13} & Control & 1.0 & 1.0 & 1.0 & 1.0 & 6.7 & 6.1 \\
\hline & Indomethacin & 0.66 & 1.09 & 0.92 & 0.88 & 9.3 & 3.7 \\
\hline & IL-1 & 1.72 & 1.38 & 0.37 & 2.25 & 0.14 & 7.5 \\
\hline & IL-1 + Indomethacin & 2.61 & 1.04 & 0.21 & 2.17 & 0.05 & 15.2 \\
\hline \multirow[t]{4}{*}{16} & Control & 1.0 & 1.0 & 1.0 & 1.0 & 6.3 & 4.5 \\
\hline & Indomethacin & 1.05 & 0.87 & 0.87 & 0.71 & 4.8 & 5.7 \\
\hline & IL-1 & 3.98 & 1.29 & 0.06 & 2.41 & 0.09 & 11.4 \\
\hline & IL-1 + Indomethacin & 3.72 & 0.85 & 0.04 & 2.00 & 0.08 & 14.6 \\
\hline \multirow[t]{4}{*}{20} & Control & 1.0 & 1.0 & 1.0 & 1.0 & 6.54 & 6.54 \\
\hline & Indomethacin & 0.99 & 0.94 & 1.02 & 0.69 & 7.18 & 7.18 \\
\hline & IL-1 & 0.81 & 0.53 & 0.03 & 0.98 & 0.26 & 0.26 \\
\hline & IL-1 + Indomethacin & 0.74 & 0.51 & 0.02 & 0.97 & 0.13 & 0.13 \\
\hline
\end{tabular}

* Chondrocytes (female, 5 1/2; see Figs. 4 and 5 and Table III) were incubated from day 2 of culture in 100-mm dishes in DME with 10\% FCS containing no addition (control), $1 \mu \mathrm{M}$ indomethacin, $2.5 \mathrm{pM}$ IL-1, or IL-1 and indomethacin. Cytoplasmic RNA was extracted on the days indicated above as described in Methods. $¥$ Values are treated/control ratios of areas of peaks obtained after densitometric scanning of autoradiographs shown in Fig. 5. Ratios of different procollagen mRNAs were also determined after correcting for specific activities of the ${ }^{32} \mathrm{P}-$-labeled DNA probes.

collagen synthesis is at the level of $\alpha 1(\mathrm{I})$ rather than $\alpha 2(\mathrm{I})$ procollagen mRNA $(20,23,36)$. Incubation with IL- 1 in the presence of indomethacin therefore, increased the ratio of $\alpha 1(\mathrm{I}) / \alpha 2$ (I) procollagen mRNAs. Levels of $\alpha 1$ (III) procollagen mRNA were not altered at the lowest plating density, but were increased by IL- 1 in the presence of indomethacin at the higher cell-plating densities.

Thus, the costal chondrocytes with respect to the expression of type I collagen appeared to be particularly sensitive to fluctuations in concentrations of $\mathrm{PGE}_{2}$ in the culture medium. When a sensitive RIA, employing [ $\left.{ }^{125} \mathrm{I}\right] \mathrm{PGE}_{2}$, was used to determine ambient $\mathrm{PGE}_{2}$ concentrations, we found that concentrations of $\mathrm{PGE}_{2}$ in medium from costal chondrocytes incubated under control conditions for $48 \mathrm{~h}$ were $10-250 \mathrm{pg} / \mathrm{ml}$ (compared with $1-10 \mathrm{ng} / \mathrm{ml}$ in culture medium from human articular chondrocytes [20]). Despite the marked differences in amounts of $\mathrm{PGE}_{2}$ synthesized by these different chondrocytes under basal conditions, the magnitude of stimulation by IL-1 of ambient $\mathrm{PGE}_{2}$ concentrations ( $\sim 40$ - to 400 -fold) in the costal chondrocytes was comparable to that previously observed in articular chondrocyte cultures (20). The levels of $\mathrm{PGE}_{2}$ in two of the experiments described above are shown in Tables III and IV. High concentrations of $\mathrm{PGE}_{2}$ were maintained during long-term incubation with IL-1 (Table III). In- cubation for 24 or $48 \mathrm{~h}$ with IL-1 in the presence or absence of indomethacin had no significant effect on cell number or DNA content. In long-term incubation, however, cell numbers increased progressively through day 20 . Treated/control ratios on day 20 were: indomethacin, 1.45; IL-1, 1.79; IL-1 plus indomethacin, 1.87). These increases in cell number did not account for the increases in collagen synthesis or cellular levels of procollagen mRNAs under these conditions.

\section{Discussion}

We showed recently that recombinant preparations of murine and human IL-1 stimulated the synthesis of types I and III collagens and fibronectin and levels of associated procollagen mRNAs in cultured human and synovial fibroblasts and articular chondrocytes (20). The latter synthesized little type II collagen at the time we examined them. This stimulatory effect was observed, however, only when IL-1-induced increases in endogenous $\mathrm{PGE}_{2}$ synthesis were blocked by indomethacin (20). In the present studies, human costal chondrocytes, which continue to synthesize type II collagen throughout primary culture, were used to further examine these effects. Since costal chondrocytes could be obtained in large numbers, they provided a model to examine regulation of synthesis of this carti-
Figure 5. Dot hybridization analysis of $\alpha 1(\mathrm{I}), \alpha 2(\mathrm{I}), \alpha 1(\mathrm{II})$, and $\alpha 1$ (III) procollagen mRNA levels in human costal chondrocytes after continuous treatment with IL- 1 and indomethacin. Chondrocytes were treated from day 2 of culture (1) alone, or with (2) $1 \mu \mathrm{M}$ indomethacin, (3) $2.5 \mathrm{pM} \mathrm{IL-1,} \mathrm{or} \mathrm{(4)} \mathrm{IL-1} \mathrm{and} \mathrm{indomethacin} \mathrm{as} \mathrm{de-}$ scribed in Table I. Cytoplasmic RNA was extracted on the days indicated one day after the previous medium change and blotted on nitrocellulose as equivalents of DNA in the nuclear pellets at three serial dilutions $(0.5,0.25$, and $0.125 \mu \mathrm{g}$ DNA equivalents, respectively). 
Table II. Procollagen mRNA Levels on Day 13 of Culture in Human Costal Chondrocytes after Plating at Different Densities: Effects of IL-1 and Indomethacin

\begin{tabular}{|c|c|c|c|c|c|c|c|}
\hline \multirow{3}{*}{$\begin{array}{l}\text { Cells plated } \\
\text { per dish* }\end{array}$} & \multirow[b]{3}{*}{ Incubation conditions ${ }^{\ddagger}$} & \multicolumn{6}{|c|}{ Procollagen $\mathrm{mRNA}^{\mathrm{s}}$} \\
\hline & & \multicolumn{4}{|c|}{ Treated/control ratios } & \multicolumn{2}{|c|}{ Ratios } \\
\hline & & $\alpha 1(\mathrm{I})$ & $\alpha 2(\mathrm{l})$ & $\alpha 1$ (II) & $\alpha 1(\mathrm{III})$ & $\alpha 1(\mathrm{II}) / \alpha 1(\mathrm{I})$ & $\alpha 1(\mathrm{I}) / \alpha 2(\mathrm{I})$ \\
\hline \multirow[t]{4}{*}{$0.5 \times 10^{6}$} & Control & 1.0 & 1.0 & 1.0 & 1.0 & 3.2 & 2.9 \\
\hline & Indomethacin & 1.16 & 0.92 & 0.72 & 0.94 & 1.98 & 3.86 \\
\hline & IL-1 & 0.32 & 0.36 & 0.13 & 0.84 & 1.33 & 2.96 \\
\hline & IL-1 + Indomethacin & 1.32 & 0.58 & 0.16 & 0.91 & 0.39 & 7.5 \\
\hline \multirow[t]{4}{*}{$1.0 \times 10^{6}$} & Control & 1.0 & 1.0 & 1.0 & 1.0 & 5.19 & 3.77 \\
\hline & Indomethacin & 0.93 & 1.12 & 0.86 & 0.92 & 4.77 & 3.16 \\
\hline & IL-1 & 0.41 & 0.63 & 0.18 & 1.09 & 2.30 & 2.21 \\
\hline & IL-1 + Indomethacin & 2.32 & 1.30 & 0.32 & 1.61 & 2.72 & 6.71 \\
\hline \multirow[t]{4}{*}{$1.5 \times 10^{6}$} & Control & 1.0 & 1.0 & 1.0 & 1.0 & 7.28 & 4.13 \\
\hline & Indomethacin & 0.96 & 0.83 & 0.92 & 0.93 & 10.15 & 3.24 \\
\hline & IL-1 & 0.42 & 0.79 & 0.13 & 1.15 & 2.18 & 2.16 \\
\hline & IL-1 + Indomethacin & 1.37 & 0.94 & 0.16 & 1.68 & 0.86 & 6.04 \\
\hline \multirow[t]{4}{*}{$2.0 \times 10^{6}$} & Control & 1.0 & 1.0 & 1.0 & 1.0 & 12.03 & 2.32 \\
\hline & Indomethacin & 1.04 & 0.77 & 1.17 & 1.30 & 12.20 & 3.45 \\
\hline & IL-1 & 0.75 & 0.77 & 0.17 & 1.63 & 2.54 & 2.43 \\
\hline & IL-1 + Indomethacin & 2.90 & 1.0 & 0.19 & 1.86 & 0.76 & 7.03 \\
\hline
\end{tabular}

* Chondrocytes (female, $5 \mathrm{1} / 2$; see Table I) were plated on day 0 in 100 -mm dishes. ${ }^{\ddagger}$ On day 12 of culture cells were incubated for a further $24 \mathrm{~h}$ alone or with $1 \mu \mathrm{M}$ indomethacin, $5 \mathrm{pM}$ IL-1 or IL-1 and indomethacin in DME with $10 \%$ FCS. $\$$ Values are treated/control ratios of areas of peaks obtained after densitometric scanning of RNA dot blots. Cytoplasmic RNA was blotted as equivalents of DNA in the nuclear pellets after extraction as described in Methods. DNA content $(72 \mu \mathrm{g} \pm 2.8 \mathrm{SE})$ was similar in all plates regardless of plating densities after the 13 $\mathrm{d}$ of culture. Ratios of different procollagen mRNAs were also determined after correcting for specific activities of the ${ }^{32} \mathrm{P}$-labeled DNA probes.

lage-specific product. In contrast to the stimulatory effects of IL-1 on expression of types I and III collagens, suppression by IL-1 of synthesis of type II collagen and associated levels of $\alpha 1$ (II) procollagen mRNA was found even in the presence of the cyclooxygenase inhibitor. IL-1 also suppressed the levels of mRNA for $\alpha 1$ (IX) procollagen, another cartilage-specific collagen. In addition, IL-1, while accelerating the loss of cartilage-specific phenotype, induced the synthesis of types I and III collagens and fibroblast-like morphology in early chondrocyte cultures. The effects of this natural inflammatory cytokine are, in some respects, similar to those produced by ascorbate (37, 38), Rous-sarcoma virus (39), retinol derivatives (40), or bromodeoxyuridine (41). Thus, in addition to increasing synthesis of proteinases and prostaglandins, products that are involved in degradation of connective tissues, IL-1 is capable of modulating collagen synthesis and regulating the relative amounts of different collagen types. Such changes in collagen synthesis could result in inappropriate repair following degradation of the cartilage matrix.

In previous studies we noted that IL-1-induced increases in $\mathrm{PGE}_{2}$ levels in culture medium can alter the phenotypic expression of connective tissue cells $(19,20)$. In synovial fibroblasts and articular and costal chondrocytes the suppression of type I collagen synthesis is probably secondary to the effects of increased ambient concentrations of $\mathrm{PGE}_{2}$ induced by IL-1. Although basal levels of $\mathrm{PGE}_{2}$ in cultures of costal chondrocytes are $\sim 1-5 \%$ those of articular chondrocytes, the synthesis of $\mathrm{PGE}_{2}$ by both cell types is increased by approximately the

Table III. Prostaglandin $E_{2}$ Production by Human Costal Chondrocytes after Long-Term Incubation with IL-1 and Indomethacin

\begin{tabular}{lcccc}
\hline & \multicolumn{4}{c}{ PGE $_{2}$ (Pg per 10 $\mu \mathrm{g}$ DNA*) } \\
\cline { 2 - 5 } \multicolumn{1}{c}{ Incubation condition } & Day 7 & Day 13 & Day 16 & Day 20 \\
\cline { 2 - 5 } Control & $265 \pm 54(1.0)^{\ddagger}$ & $373 \pm 15(1.0)$ & $1,070 \pm 90(1.0)$ & $609 \pm 21(1.0)$ \\
Indomethacin & $84 \pm 6.2(0.32)$ & $61 \pm 8.0(0.16)$ & $94 \pm 13.0(0.09)$ & $47 \pm 8.0(0.08)$ \\
IL-1 & $5,190 \pm 1,480(19.6)$ & $39,800 \pm 2,360(107)$ & $17,610 \pm 1,070(16.5)$ & $50,220 \pm 2,210(82.5)$ \\
IL-1 + Indomethacin & $79 \pm 3.0(0.30)$ & $62 \pm 11.0(0.17)$ & $60 \pm 1.0(0.06)$ & $44 \pm 7.0(0.07)$
\end{tabular}

* PGE $_{2}$ levels were measured in the $24 \mathrm{~h}$ preincubation medium of the cells in 12-well plates used for the experiment shown in Fig. 4 . ${ }^{\ddagger}$ Values are means \pm SEM of triplicate wells. $10^{6}$ cells contained $\sim 10 \mu \mathrm{g}$ of DNA. Numbers in parentheses are treated/control ratios. 
Table IV. Prostaglandin $E_{2}$ Production by Human Costal Chondrocytes Plated at Different Densities: Effects of IL-1 and Indomethacin

\begin{tabular}{|c|c|c|c|c|}
\hline \multirow[b]{3}{*}{ Incubation condition } & \multicolumn{4}{|c|}{$\mathrm{PGE}_{2}$ (pg per $10^{6}$ cells*) } \\
\hline & \multicolumn{4}{|c|}{ Cells plated per dish } \\
\hline & $0.5 \times 10^{6}$ & $1.0 \times 10^{6}$ & $1.5 \times 10^{6}$ & $2.0 \times 10^{6}$ \\
\hline Control & $93(1.0)^{\ddagger}$ & $62(1.0)$ & $77(1.0)$ & $74(1.0)$ \\
\hline Indomethacin & $33(0.36)$ & $17(0.27)$ & $18(0.24)$ & $18(0.24)$ \\
\hline IL-1 & $32,016(344)$ & $23,776(386)$ & $25,179(328)$ & $27,356(372)$ \\
\hline IL-1 + Indomethacin & $27(0.29)$ & $23(0.37)$ & $29(0.37)$ & $59(0.81)$ \\
\hline
\end{tabular}

* $\mathrm{PGE}_{2}$ was measured by RIA in the preincubation medium from the cells from which cytoplasmic RNA was extracted for the dot blots in Table II. Cell number was similar regardless of plating density and significant differences due to treatment were not observed during the 24-h preincubation period. ${ }^{\ddagger}$ Numbers in parentheses are treated/control ratios. Values are averages of duplicate determinations with SD $<5 \%$.

same order of magnitude after treatment with IL-1. The modulatory effects of $\mathrm{PGE}_{2}$, therefore, cannot be related directly to the absolute concentrations of $\mathrm{PGE}_{2}$ in the medium. Observations in human dermal fibroblasts that IL-1 induces a 50-100-fold increase in $\mathrm{PGE}_{2}$ levels without suppression of type I collagen synthesis or procollagen mRNA levels support this conclusion (19-22). There are several possible explanations for the differential effects of $\mathrm{PGE}_{2}$ on the various cell types. The number of cellular $\mathrm{PGE}_{2}$ receptors or their binding affinity could be characteristically different for each cell type or could change with time of culture. This might account for the finding in the present study that continuous exposure to IL-1 leads to escape from the inhibitory effects of $\mathrm{PGE}_{2}$ on type I collagen synthesis. Thus, by day 7 in culture IL-1, even in the presence of indomethacin, increases expression of type I collagen mRNA despite marked increases in medium $\mathrm{PGE}_{2}$ levels. The escape from the inhibitory effects of $\mathrm{PGE}_{2}$ observed after long-term exposure to IL-1 could be related to downregulation of $\mathrm{PGE}_{2}$ receptor function induced by prolonged exposure to high ambient $\mathrm{PGE}_{2}$ levels.

The augmentation by IL-1 of synthesis of types I and III collagens when the cytokine-induced increase in endogenous $\mathrm{PGE}_{2}$ production is inhibited is reminiscent of the "upregulation" of hormone-induced adenylate cyclase responses observed in synovial cells and chondrocytes coincubated with IL-1 and indomethacin (42-44). Since responses to forskolin are also augmented by preincubation with IL-1 (45), IL-1 may modulate indirectly the adenylate cyclase/G protein complex. Such "crosstalk" between adenylate cyclase-coupled signal pathways and the inositol lipid pathway, with its distinct $G$ protein has been demonstrated $(46,47)$. Although the cell surface receptors for IL-1 have been measured and characterized in several responsive cell types (48), the signal pathways involved in transducing IL-1 effects have not yet been defined.

One of the interesting observations that has resulted from the present study is that IL-1 produces differential effects on the expression of genes for types I and III collagens compared with types II and IX collagens. Since the effects on protein synthesis parallel those on the respective mRNA levels, control is most likely pretranslational, probably occurring at a transcriptional level, although effects on mRNA stability have not yet been ruled out. Although it is not known how IL-1 acts intracellularly, several of its effects are similar to those of phorbol esters including stimulation of the expression of the procollagenase gene (17). It is tempting to speculate that the procollagen genes would contain cis-acting DNA sequences similar to those responsive to phorbol esters, which would function in a different manner in regulating transcription of the types I and III compared to types II and IX procollagen genes. Although one phorbol ester-inducible sequence is recognized by activator protein 1 (AP-1) $(49,50)$, the trans-acting factors responsible for the regulatory effects of IL-1 on procollagen gene expression have not been defined. The DNA sequences required for regulation by CAMP and phorbol ester map to the same region of the proenkephalin gene promoter (51) suggesting that the two intracellular signaling pathways converge to regulate a common trans-acting factor. The activator protein-2 (AP-2) also responds to both cAMP and phorbol ester (52). Since IL-1 and $\mathrm{PGE}_{2}$ have different effects on expression of different collagen genes, it is possible that signals induced by these mediators may interact with the different collagen genes (on different chromosomes) in specific ways.

A number of the previously described effects of soluble mononuclear cell products on mesenchymal cells can be attributed to IL-1 based on studies using recombinant preparations of this cytokine. It is likely that other factors produced by mononuclear cells have similar and even synergistic effects. For example, in preliminary work in our laboratory tumor necrosis factor- $\alpha$ and tumor necrosis factor- $\beta$ (lymphotoxin) alter synthesis of types I and III collagens in synovial fibroblasts in a manner similar to IL-1 (Amento, E. P., M. Hayes, and S. M. Krane, unpublished observations). Furthermore these cytokines act synergistically with transforming growth factor- $\beta$. In vivo, therefore, it is likely that the regulation of collagen synthesis results from the cumulative effects of different ligands several of which are products of mononuclear cells present at sites of inflammation.

Mediators such as IL-1 could also have a role in cartilage development, analogous to that proposed for ameboid microglia in the developing brain. The ameboid microglia, which are the mononuclear phagocytic cells of the brain, may regulate through signaled release of IL-1 the proliferation of astroglia $(53,54)$. Cartilage is an avascular tissue, and it is possible that mononuclear phagocytes derived from the circulation alter the chondrocyte phenotype when vascularization takes place in the process of ossification of cartilage in the endochondral sequence. Factors such as IL-1 could then alter the chondrocyte phenotype by suppressing synthesis of the cartilage-specific types II and IX collagens and inducing synthesis of type I collagen characteristic of mineralized bone. These 
responses attributable to IL-1 are analogous to these involved in the repair of cartilage matrix in inflammatory conditions.

\section{Acknowledgments}

We thank M. Angelo for preparation of the manuscript, S. Goldring for helpful comments, $\mathrm{M}$. Byrne for the $\mathrm{CNBr}$ peptide analyses and $\mathrm{J}$. Glowacki for providing samples of costal cartilage.

This work was supported by U.S. Public Health Service grants AM-03564, AM-07258 and AM-03490. This is publication number 1045 of the Robert W. Lovett Memorial Group for the Study of Diseases Causing Deformities.

\section{References}

1. Krane, S. M., E. P. Amento, M. B. Goldring, S. R., Goldring, M. L. Stephenson, B. Polla, S. Arai, A. K. Bhan, and J. T. Kurnick. 1986. Cellular interaction and matrix destruction during inflammatory processes within the joints. In Articular Cartilage Biochemistry. K. Kuettner, R. Schleyerbach, and V. C. Hascall, editors. Raven Press, Inc., New York. 413-422.

2. Kobayashi, I., and M. Ziff. 1975. Electron microscopic studies of the cartilage-pannus junction in rheumatoid arthritis. Arthritis Rheum. 18:475-483.

3. Weissmann, G. 1982. Activation of neutrophils and the lesions of rheumatoid arthritis. J. Lab. Clin. Med. 100:322-333.

4. Mitchell, N. S., and N. Shepard. 1978. Changes in proteoglycan and collagen in cartilage in rheumatoid arthritis. J. Bone Joint Surg. 60A:349-354.

5. Pelletier, J.-P., J. Martel-Pelletier, R. D. Altman, L. GhandurMnaymneh, D. S. Howell, and J. F. Woessner, Jr. 1983. Collagenolytic activity and collagen matrix breakdown of the articular cartilage in the Pond-Nuki dog model of osteoarthritis. Arthritis Rheum. 26:866-874.

6. Fell, H. B., and R. W. Jubb. 1977. The effect of synovial tissue on the breakdown of articular cartilage in organ culture. Arthritis Rheum. 20:1359-1371.

7. McGuire-Goldring, M. K. B., G. Murphy, M. Gowen, J. E. Meats, N. M. Ebsworth, C. Poll, J. J. Reynolds, and R. G. G. Russell. 1983. Effects of retinol and dexamethasone on cytokine-mediated control of metalloproteinases and their inhibitors by human articular chondrocytes and synovial cells in culture. Biochim. Biophys. Acta. 763:129-139.

8. Meats, J. E., M. B. McGuire, and R. G. G. Russell. 1980. Human synovium releases a factor which stimulates chondrocyte production of PGE and plasminogen activator. Nature (Lond.). 286:891-892.

9. Meats, J. E., M. K. B. McGuire, N. M. Ebsworth, D. J. Englis, and R. G. G. Russell. 1984. Enhanced production of prostaglandins and plasminogen activator during activation of human articular chondrocytes by products of mononuclear cells. Rheumatol. Int. 4:143149.

10. Eyre, D. R., C. A. McDevitt, M. E. J. Billingham, and H. Muir. 1980. Biosynthesis of collagen and other matrix proteins by articular cartilage in experimental osteoarthrosis. Biochem. J. 188:823-837.

11. Krane, S. M., E. P. Amento, M. B. Goldring, S. R. Goldring, and M. L. Stephenson. 1988. Modulation of matrix synthesis and degradation in joint inflammation. In The Control of Tissue Damage. A. M. Glauert, editor. Elsevier Science, Amsterdam. 179-195.

12. Dayer, J.-M., B. de Rochemonteix, B. Burrus, S. Demczuk, and C. A. Dinarello. 1986. Human recombinant interleukin 1 stimulates collagenase and prostaglandin $\mathrm{E}_{2}$ production by human synovial cells. J. Clin. Invest. 77:645-648.

13. Leizer, T., B. J. Clarris, P. E. Ash, J. van Damme, J. Saklatvala, and J. A. Hamilton. 1987. Interleukin- $1 \beta$ and interleukin- $1 \alpha$ stimulate the plasminogen activator activity and prostaglandin $E_{2}$ levels of human synovial cells. Arthritis Rheum. 30:562-566.

14. McGuire-Goldring, M. B., J. E. Meats, D. D. Wood, E. J. Ihrie,
N. M. Ebsworth, and R. G. G. Russell. 1984. In vitro activation of human chondrocytes and synoviocytes by a human interleukin-1-like factor. Arthritis Rheum. 27:654-662.

15. Mizel, S. B., J.-M. Dayer, S. M. Krane, and S. E. Mergenhagen. 1981. Stimulation of rheumatoid synovial cell collagenase and prostaglandin production by partially purified lymphocyte-activating factor (interleukin 1). Proc. Natl. Acad. Sci. USA. 78:2474-2477.

16. Rupp, E. A., P. M. Cameron, C. S. Ranawat, J. A. Schmidt, and E. K. Bayne. 1986. Specific bioactivities of monocyte-derived interleukin $1 \alpha$ and interleukin $1 \beta$ are similar to each other on cultured murine thymocytes and on cultured human connective tissue cells. $J$. Clin. Invest. 78:836-839.

17. Stephenson, M. L., M. B. Goldring, J. R. Birkhead, S. M. Krane, H. J. Rahmsdorf, and P. Angel. 1987. Stimulation of procollagenase synthesis parallels increases in cellular procollagenase mRNA in human articular chondrocytes exposed to recombinant interleukin $1 \beta$ or phorbol ester. Biochim. Biophys. Res. Commun. 144:583-590.

18. Wood, D. D., E. K. Bayne, M. B. Goldring, M. Gowen, D. Hamerman, J. L. Humes, E. J. Ihrie, P. E. Lipsky, and M.-J. Staruch. 1985. The four biochemically distinct species of human interleukin 1 all exhibit similar biologic activities. J. Immunol. 134:895-903.

19. Krane, S. M., J.-M. Dayer, L. S. Simon, and M. S. Byrne. 1985. Mononuclear cell-conditioned medium containing mononuclear cell factor (MCF), homologous with interleukin 1, stimulates collagen and fibronectin synthesis by adherent rheumatoid synovial cells: effects of prostaglandin $\mathrm{E}_{2}$ and indomethacin. Collagen Rel. Res. 5:99-117.

20. Goldring, M. B., and S. M. Krane. 1987. Modulation by recombinant interleukin 1 of synthesis of types I and III collagens and associated procollagen mRNA levels in cultured human cells. J. Biol. Chem. 262:16724-16729.

21. Kahari, V.-M., J. Heino, and E. Vuorio. 1987. Interleukin-1 increases collagen production and $\mathrm{mRNA}$ levels in cultured skin fibroblasts. Biochem. Biophys. Acta. 929:142-147.

22. Postlethwaite, A. E., R. Raghow, G. P. Stricklin, H. Poppleton, J. M. Seyer, and A. H. Kang. 1988. Modulation of fibroblast functions by interleukin 1: Increased steady-state accumulation of type I procollagen messenger RNAs and stimulation of other functions but not chemotaxis by human recombinant interleukin $1 \alpha$ and $\beta$. J. Cell Biol. 106:311-318.

23. Goldring, M. B., L. J. Sandell, M. L. Stephenson, and S. M. Krane. 1986. Immune interferon suppresses levels of procollagen mRNA and type II collagen synthesis in cultured human articular and costal chondrocytes. J. Biol. Chem. 261:9049-9056.

24. Wingfield, P., M. Payton, J. Tavernier, M. Barnes, A. Shaw, K. Rose, M. G. Simona, S. Demczuk, K. Williamson, and J.-M. Dayer. 1986. Purification and characterization of human interleukin- $1 \beta$ expressed in recombinant Escherichia coli. Eur. J. Biochem. 160:491497.

25. Miller, E. J., E. H. Miller, and K. A. Piez. 1971. Identification of three genetically distinct collagens by cyanogen bromide cleavage of insoluble human skin and cartilage collagen. Biochem. Biophys. Res. Commun. 42:1024.

26. White, B. A., and F. C. Bancroft. 1982. Cytoplasmic dot hybridization. Simple analysis of relative mRNA levels in multiple small cell or tissue samples. J. Biol. Chem. 257:8569-8572.

27. Cox, R. A. 1968. The use of guanidinium chloride in the isolation of nucleic acids. Methods Enzymol. 12:120-129.

28. Strohman, R. C., P. S. Moss, J. Micou-Eastwood, D. Spector, A. Przybyla, and B. Paterson. 1977. Messenger RNA for Myosin Polypeptides: isolation from single myogenic cell cultures. Cell. 10:265273.

29. Chu, M.-L., J. C. Myers, M. P. Bernard, J.-F. Ding, and F. Ramirez. 1982. Cloning and characterization of five overlapping cDNAs specific for the human pro $\alpha$ 1(I) collagen chain. Nucleic Acids Res. 10:5925-5934.

30. Bernard, M. P., J. C. Myers, M.-L. Chu, F. Ramirez, E. F. Eikenberry, and D. J. Prockop. 1983. Structure of a cDNA for the pro 22 chain of human type I procollagen. Comparison with chick 
cDNA for pro $\alpha 2$ (I) identifies structurally conserved features of the protein and the gene. Biochemistry. 22:1139-1145.

31. Sandell, L. J. 1984. Characterization of a human type II procollagen gene. J. Cell Biol. 99:405a. (Abstr.)

32. Sandell, L. J. 1985. Characterization of a human type II procollagen gene. Orthoped. Trans. 10:160.

33. Miskulin, M., R. Dalgleish, B. Kluve-Beckerman, J. I. Rennard, P. Tolstoshev, M. Brantly, and R. G. Crystal. 1986. Human type III collagen gene expression is coordinately modulated with type I collagen genes during fibroblast growth. Biochemistry. 25:1408-1413.

33a. Kimura, T., M.-G. Mattei, J. W. Stevens, M. B. Goldring, Y. Ninomiya, and B. R. Olsen. 1988. Molecular cloning of rat and human type IX collagen cDNA. Eur. J. Biochem., In press.

34. Ponte, P., P. Gunning, H. Blau, and L. Kedes. 1983. Human actin genes are single copy for $\alpha$-skeletal and $\alpha$-cardiac actin but multicopy for $\beta$ - and $\gamma$-cytoskeletal genes: $3^{\prime}$ untranslated regions are isotype specific but are conserved in evolution. Mol. Cell. Biol. 3:17831791.

35. Laskey, R. A., and A. D. Mills. 1977. Enhanced autoradiographic detection of ${ }^{32} \mathrm{P}$ and ${ }^{125} \mathrm{I}$ using intensifying screens and hypersensitized film. FEBS (Fed. Eur. Biochem. Soc.) Lett. 82:314-316.

36. Stephenson, M. L., S. M. Krane, E. P. Amento, P. A. McCroskery, and M. Byrne. 1985. Immune interferon inhibits collagen synthesis by rheumatoid synovial cells associated with decreased levels of the procollagen mRNAs. FEBS (Fed. Eur. Biochem. Soc.) Lett. 180:4350 .

37. Daniel, J. C. B. U. Pauli, and K. E. Kuettner. 1984. Synthesis of cartilage matrix by mammalian chondrocytes in vitro. III. Effects of ascorbate. J. Cell Biol. 99:1960-1969.

38. Sandell, L. J., and E. Dudek. 1985. Effects of ascorbic acid and aging on collagen mRNA in articular chondrocytes. J. Cell Biol. 101:94a.

39. Allebach, E. S., D. Boettiger, M. Pacifici, and S. L. Adams. 1985. Control of types I and II collagen and fibronectin gene expression in chondrocytes delineated by viral transformation. Mol. Cell. Biol. 5:1002-1008.

40. Hein, R., T. Krieg, P. K. Mueller, and O. Braun-Falco. 1984. Effect of retinoids on collagen production by chondrocytes in culture. Biochem. Pharmacol. 33:3263-3267.

41. Mayne, R., M. S. Vail, and E. J. Miller. 1975. Analysis of changes in collagen biosynthesis that occur when chick chondrocytes are grown in 5-bromo-2'-deoxyuridine. Proc. Natl. Acad. Sci. USA. 72:4511-4515.

42. Dayer, J.-M., S. R. Goldring, D. R. Robinson, and S. M. Krane. 1979. Effects of human mononuclear cell factor on cultured rheuma- toid synovial cells. Interactions of prostaglandin $\mathrm{E}_{2}$ and cyclic adenosine 3',5'-monophosphate. Biochim. Biophys. Acta. 586:87-105.

43. Goldring, S. R., J.-M. Dayer, and S. M. Krane. 1984. Rheumatoid synovial cell hormone responses modulated by cell-cell interactions. Inflammation. 8:107-121.

44. Houston, J. P., M. K. B. McGuire, J. E. Meats, N. M. Ebsworth, R. G. G. Russell, A. Crawford, and S. MacNeil. 1982. Adenylate cyclase of human articular chondrocytes. Responsiveness to prostaglandins and other hormones. Biochem. J. 208:35-42.

45. Goldring, S. R., M. S. Roelke, K. K. Petrison, A. E. Evins, and S. M. Krane. 1987. Mechanisms by which monocyte-macrophage products regulate responses of connective tissue (bone and synovial) cells to hormones. J. Bone Miner. Res. 2:S239.

46. Wakelam, M. J. O., G. J. Murphy, V. J. Hruby, and M. D. Houslay. 1986. Activation of two signal-transduction systems in hepatocytes by glucagon. Nature (Lond.). 323:68-71.

47. Yoshimasa, T., D. R. Sibley, M. Bouvier, R. J. Lefkowitz, and M. G. Caron. 1987. Cross-talk between cellular signalling pathways suggested by phorbol-ester-induced adenylate cyclase phosphorylation. Nature 327:67-70.

48. Dower, S. K., and D. L. Urdal. 1987. The interleukin-1 receptor. Immunol. Today. 8:46-51.

49. Angel, P., I. Baumann, B. Stein, H. Delius, H. J. Rahmsdorf, and P. Herrlich. 1987. 12-O-Tetradecanoyl-phorbol-13-acetate induction of the human collagenase gene is mediated by an inducible enhancer element located in the 5 '-flanking region. Mol. Cell. Biol. 7:2256-2266.

50. Angel, P., M. Imagawa, R. Chiu, B. Stein, R. J. Imbra, H. J. Rahmsdorf, C. Jonat, P. Herrlich, and M. Karin. 1987. Phorbol ésterinducible genes contain a common cis element recognized by a TPAmodulated trans-acting factor. Cell. 49:729-739.

51. Comb, M., N. C. Birnberg, A. Seasholtz, E. Herbert, and H. M. Goodman. 1986. A cyclic AMP- and phorbol ester-inducible DNA element. Nature 323:353-356.

52. Imagawa, M., R. Chiu, and M. Karin. 1987. Transcription factor AP-2 mediates induction by two different signal-transduction pathways: Protein kinase $C$ and cAMP. Cell. 51:251-260.

53. Giulian, D., R. L. Allen, T. J. Baker, and Y. Tomozawa. 1986. Brain peptides and glial growth. I. Glia-promoting factors as regulators of gliogenesis in the developing and injured central nervous system. $J$. Cell Biol. 102:803-811.

54. Giulian, D., T. J. Baker, L.-C. N. Shih, and L. B. Lachman. 1986. Interleukin 1 of the central nervous system is produced by ameboid microglia. J. Exp. Med. 164:594-604. 